\title{
Indonesia as the Best Halal Tourism Destination and its Impacts to Muslim's Travelers Visit
}

\author{
Anton Minardi, Dewi Astuti, and Suhadi
}

\section{ABSTRACT}

The article described at first conceptual of halal tourism which is based on Islamic Shariah. Second, analyses of halal tourism effectiveness practically. Third, research of Indonesia as biggest Muslim populations in the world provide and serve halal tourism. To research this thing authors used a descriptive analytical research method coupled with literacy techniques. As a summary that halal tourism is growing fast in Indonesia with some special advantages and efforts actually. Evidently, Indonesia has been selected as the best halal tourism in the world by 2019 and the trend of increasing visitors especially from middle east whom mostly Muslim's travelers to the country. The implications of the research are found relatively new development of halal tourism conceptually and the implications in promoting halal tourism, serving Muslims community to get satisfactions in tourism without deny their belief, halal tourism is a health tourism that provide only foods, beverages and healthy advertisement and also green tourism that secure environment practically. Practical implications there are first, promote halal tourism. Second, serve Muslims community to get satisfactions in tourism without deny their belief and Islamic tennets. Third, halal tourism is a health tourism that provide only foods, beverages and healthy advertisement and green tourism that secure environment. The article is original as a result of a research in international issue that concern of halal tourism which service tourists specially for Muslims, and also offers new platform in tourism business.

Keywords: Destination, Halal Tourism, Indonesia, Muslim, Traveller.
Published Online: July 30, 2021

ISSN: 2736-5514

DOI : $10.24018 /$ theology.2021.1.3.30

\section{Anton Minardi}

Pasundan University, Indonesia. (e-mail:

abdurrahmananton1975@gmail.com)

Dewi Astuti

Pasundan University, Indonesia.

(e-mail: dewi.astuti@unpas.ac.id) Suhadi

Pasundan University, Indonesia.

*Corresponding Author

\section{INTRODUCTION}

The study of International Relations always become the highlight of the world, where the study includes the variety of things that involved the relationship between state and non-state. The study of International Relations is a part of sociology that focus on the international community (sociology of International Relation). In order words, the study of International Relations not just focus on politics, but also covers on economic social, culture, defense, and others like the relocate community (migration and emigration), tourism, olympic (sport), or changes in a culture (culture exchange).

Speaking of the International Relations, tourism become the hot topic in the study of International Relations. With this, the tourism become one of the topics that attract the actor of international where the uniqueness of expansion. Tourism also becomes one of the field that can lift up the job opportunities, business and service, community opinion, economic of country as well as the other field either in a direct or indirect way that can give the good impact on the country.

As the progress on the topic about the tourism, some new creation arises on the international business or local in the opportunities that resulting by tourism and becoming the promising among the actor tourism, one of it was halal tourism. This becomes the focus in this research.

The term halal tourism starts from 2015 where the agenda of World Halal Tourism Summit held in Abu Dhabi, UAE. With that, many countries joined to perform all the tourism that their own country have. Indonesia become the one of the countries that follows in the competition of halal tourism and increased the quality of halal tourism in the world. The sector of Indonesia tourism has many excellent competitive and comparative.

The good performance in 2019 tapped by the sector of the halal tourism Indonesia sector that resulted in the rating number one halal tourism version Mastercard-Cresent Rating Global Travel Index (GMTI) 2019, increased to one stage compared to the year before. Through the success it stabilizes the halal tourism expanded vision to "create Indonesia to become the destination country of halal tourism world level". There are 4 missions of the halal tourism expanded, which is expanding the destination of halal tourism world level, expand the ecosystem and industry in halal tourism which is highly competitive, increase capital and constitution capabilities of halal tourism national and do marketing with oriented to market target. 
While on the district level, based on the Indonesia Muslim travel index on 2019, the province of Lombok (stage 1), Aceh (stage 2), Riau and Kepri (stage 3), Jakarta (stage 4), Sumatera Barat (stage 5), and Jawa Barat (stage 6). The acceleration team of halal tourism win Republik of Indonesia have entered the 4 aspect that focus on the strategy development of halal tourism which is destination, industry, progression, and marketing.

The countries continue to compete in increasing the quality service of tourism by using the increase of visit of foreign tourism in compete of the global world. In 2017, the total of journey of foreign tourism global Muslim counted in the 131 million of people. In 2020, the amount increases to 156 million and the money circulation will gain USD220 million. In the era of global world, the big city at country with the majority population of Muslim community still become the main point of tourist, like Arab Saudi, Turki, UEA, Malaysia until Indonesia. This becomes the increase in service of the halal tourism at various country so that it can attract to visit the country of halal tourism.

Indonesia became the majority country of Muslim the largest in the world and become the popular places for foreign tourist, especially the Muslim tourist. In the peaceful community that have no discrimination by the minority religion, this has become the attraction by itself by the tourists to visit also enjoy the beauty and religion of Indonesia. In the talk of Indonesia, the most common things that came through our mind is that this country rich in natural resources and also human resources.

Based on the data of Lonely Planet, Indonesia enter the stage 7 , the best country for vacation in 2019. One of the guide of the original journey English, rough guides also launched list of 20 country that beauty comes within of the world in 2019 and Indonesia have gain at stage 6, the country that beauty comes within in the world [1]. This has become the positive impact in development of halal tourism at Indonesia, and the value can be seen from the amount of the visitor of foreign tourist that keep increase.

From the restrictions about the halal tourism and the variety of achievement that have in Indonesia in the participation in competition of the best halal tourism in the scope of world international level, then the researchers gain interested in uplifting the title: "Indonesia as the Best Halal Tourism Destination and Its Impacts to Muslim's Travelers Visit".

\section{METHOD}

Authors use a method of research for study and analysis the problem of research. As for the method that have been used in this research are the method of analysis descriptive, which is a method that been used for illustrating, classification, as well as analyze the symptoms or the phenomenon that based the result of the observation from various event and the problem that occurred [2].

\section{FINDING}

We found that after the implementation of Indonesia as Halal Tourism destination with some programmes with cumulative from January-August 2018 the visits of various travelers have been raised to 10,58 million or trending is raised $12,30 \%$ from 2017 is average 9,42 million visitors to Indonesia. Moreover, according to BPS mentioned that at the end of November 2018 visitors' amount are reached until 14,39 million and 20 million 2019 to Indonesia [3].

\section{DISCUSSION}

\section{A. The Public Review of Halal Tourism}

Based on KBBI, tour is travelling together expand knowledge, have fun, and others [4]. The meaning of tour are the activities of leisure that spending money or do the activities that have consumptive nature. The definition of tour is a process of temporary travel that have been doing by someone to another place outside of his residence. The motive of travel is because of the importance in economy, health, religion, culture, social, politic, and the importance of others. Tour are the activities of travelling that can be do alone or grouping to visit some destination with the purpose of recreation, studying the uniqueness of tour, selfdevelopment, and others in a short and temporary of time [5].

According to the World Tourism Organization (WTO) tourism is a human activity that travels and lives in destinations outside of everyday life. Generally, people give the tourist a glance, tourism is a journey, but not all travel can be said to be tourist. Tourism is a journey or as such activities are voluntary and temporary in order to enjoy the objects and attractions of the tourist.

Tourism in Arabic is called "rihlah" its means travel. The term tourism is derived from the Sanskrit word consisting of the word "pari" which means many, many times, circling, go around, or together and "travel" means travel or traveling. Tourism is a very complex phenomenon of human movement, goods, and a very complex service. It is closely related to the organization, the constitutional and individual relationships, the service needs, the provision of service needs, and others. Tourism is temporarily relocating people to destinations outside of their home and workplace and carrying out activities during the destination as well as setting up facilities to meet their needs.

Tourism comes from two words: pari and tourism. Pari can be interpreted as multiple, many times, spin around or complete. While Travel can be defined as travel or traveling in this case it is synonymous with the word "reavel" in English. On the basis of this, the word "tourism" can also be interpreted as traveling over and over from other places in the English language also referred to by the term "Tour" which is etymologically derived from the word torah (ibrani) meaning study, tornus (Latin) meaning tool to create a circle and in ancient French called tour which meant circling the circuit. The definition of tourism has different meanings in the opinion of experts. But the basic of the tour is that it is a journey to the destination of the desired destination outside of everyday activities in the context of entertainment, entertaining, seeking knowledge, and entertaining / recovering a person in the daily activities to return to a state of being normal or fresh. 
Travel has several characteristics: It is temporary that in the short term the tourist will return to his or her destination, involves components of travel components, it is usually done by visiting tourist objective and tourist attractions, purposes for fun and contribute to the income of the people or the areas they visit.

One thing to know is that there are divisions in the world of travel, which are divided into three kinds of orientations. First, the countries that participate in the management of its tourism sectors, such as Hawaii, Bermuda, the Caribbean, Canary Island, and others. Second, countries that consider the tourism sector to be an important sector, such as Indonesia, Singapore, Malaysia, UK, USA, OECD countries (Organization for Economic Cooperation and Development), Third, countries that consider tourism sector as supporting sectors, such as Iran, Brunei, Saudi Arabia, and others. The basic reason for the country to prioritize tourism is that all resources used and allocated are as efficient as possible and can contribute significantly to the economy of the country.

\section{B. Understanding Halal Tourism}

Organization of Islamic Confrence (OIC) defined that halal tourism base on the Qur'an's tennet at surah AlAnkabut (29) verses 20, which recommend peoples to spread on the earth and take the lessons from Allah's creations [6].

Halal tourism is a collection of a wide range of goods and services that include six elements, namely: attraction, accessibility, amenities, attractiveness, convenience and cooperation aimed at serving and fulfilling the needs, desire, and lifestyle of Muslim travelers [7].

According to the National Syariah Council (DSN) of the Council of Indonesian Scholars (MUI) (2016) in its ruling, sharia / halal tourism is a variety of tourist activities and is supported by various facilities and services provided by the community, businessmen, governments, and local governments, in accordance with Islamic principles of Islam. Tourism in the Arabic dictionary is called rihih means travel activities from one place to another for a specific purpose [8].

From the Islamic point of view, sharia / halal tourism cannot be separated from the three main pillars, namely faith, Islam, and courtesy. These three pillars serve as the backbone and foothold of all travel activities. Thus, the activity of travel in Islam is fibre with the values of faith, inhumanity, and piety to the almighty, Allah Almighty, who has created all forms of beauty, whether on land, sea, or air. All forms of beauty are the gift of God to His servants.

\section{The concept of Halal Tourism}

The concept of halal tourism is the concept based on Islam / shariah where religious values are the basis of this tourism. Halal tourism policy cannot be excluded from Islamic law governing Muslim life. There are five laws in Islam. First is compulsory, it is mandatory to do, if it is done, then it will be rewarded, otherwise if it is not done then get sin. Second, sunah, the sunah law means advocacy. If done, it will be rewarded, if not done is not sinful. The third is illegal, if done it will bring sin, but if left to reward. Fourth, this law of sin if done wrongly and if left to reward. The fifth law is change, if done unacceptably and without sin and if not done without merit and sin. Halal tourism can be interpreted as a process of incorporating Islamic or Shariah values into all aspects of tourism activities.

In general, there are 4 (four) basic concepts of halal tourism namely:

- First, food and beverages are guaranteed to be safe.

- Second, there is a convenient and convenient facility for washing with water.

- Third, there is a convenient place for worship.

- Forth, service products and services on businesses along with tourist attractions, conducive to halal lifestyle [9].

The first concept is about the delicacy of food and drink. In the Islamic literature, the term "halal" refers to everything commanded in religious teaching and forms the basis for the conduct and activities of Muslims. In particular, halal is used to mean everything that can be consumed in accordance with the Quran or the Hadith of the Prophet. Therefore, a Muslim is obliged to follow the precepts set by the teachings of Islam. The word "halal" means something that is allowed and usually used for legal purposes. The halal meaning of a beverage according to Islam is a non-alcoholic drink, this is explained in Qur'an (QS. Al-Baqarah 219). Halal in the second beverage is the halal beverage and its process, in this case the beverage and the process of getting it according to Islamic rules. Examples of alcoholic beverages are impurities, not blood, and so on. Second, it is lawful to get it, for example: stolen drinks or something. Like tea or milk, it's basically a halal beverage, but if it is obtained illegally then the law is illegal. Lastly, non-harmful drinks, such as drinks that are not harmful to the physical, spiritual, or spiritual, for example: drinks that are used to destroy one's beliefs and beverages that harm the human body.

The second concept is the availability of suitable and convenient facilities for water purification. The meaning of this second concept is the availability of suitable toilets or baths, comfortable and safe water (clean from all impurities and impurities). It is very important that this second concept is a very necessary (much needed) necessity for mankind. Therefore, investors / actors in Indonesia's halal tourism development should pay close attention to this concept as it greatly affects the value and views of tourists, especially foreign tourists.

The third concept is that there are facilities for worship. This concept is very clear that Islam is very much a worshiper because it involves the relationship between god and his creation being human. The purpose of this concept is that investors / actors who develop Indonesia's halal tourism should provide and pay attention to places of worship which are mosques, museums, or empty places that in a decent condition, clean, and avoid dirt and impurities. Because a Muslim should be as comfortable as possible in getting worship facilities.

The fourth concept is that of products and services of service to businesses and tourist attractions, conducive to halal lifestyle. In this concept the products that must be provided in the tourism environment are to be guaranteed in nature, cosmetics, food, or anything else that has been approved by the religious authorities (MUI). In the field of service, one thing to note is the creation of distance between 
men and women, for example men should serve by male tourists in need of the facilities they want, while women should also serve by female travelers. Another example is the splitting of a pool or modest clothing and covering aurat according to Islam.

Indonesia has a concept in halal tourism development itself. Where the halal concept is a reference for developers and business owners in developing the halal tourism itself. Here's a table of halal tourism concepts in Indonesia.

The concept of halal / sharia tourism must meet the following key points: First, the rise of culture and the spread of Islamic values. Shariah / halal tourism should be an icon of the revival of Islamic culture, as well as information to the world that the Islamic world also contains fascinating tourist attractions as well as forms of cultural heritage. With this sharia tourism, the world community is introduced to the grandeur and grandeur of Islamic culture. Second, that tour sharia / halal should bring economic benefits to the Muslim community. Of course, this is a pragmatic goal that should not be forgotten. However, it is in this pragmatic aim that there is a noble idealism that is to care for the betterment of the well-being of the Muslims, in which context they host. That is, the syariah / halal tourism was developed with the aim of enhancing the well-being of Muslims. Third, it is desirable that such sharia / halal tourism can strengthen the confidence, identity, and confidence of Muslims in facing negative stereotypes compared to other cultures and lifestyles. It means that tourism is not just a business, it is a lifestyle, a standard of prestige for a group of people.

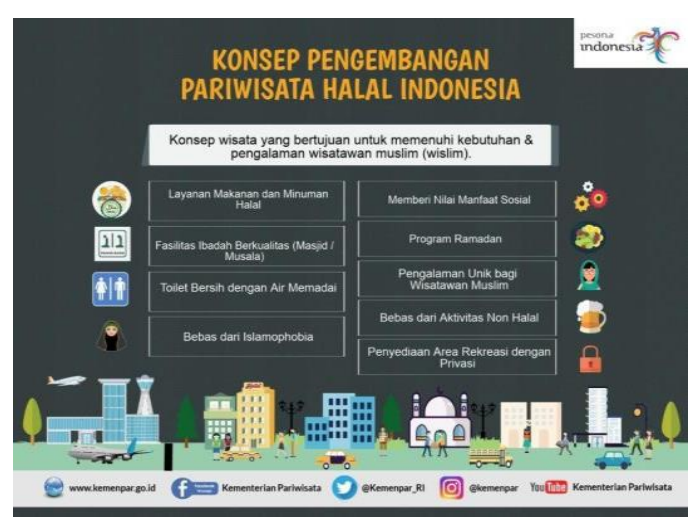

Fig. 1. The concept of development of indonesian halal tourism [10].

\section{Opportunities and Challenges}

Halal tourism is now a trend of the world, tourists are interested in the new concept. The term halal which is usually identical to food and drink is slowly starting to slow down in the lifestyle of one of them is the tourism sector. This kind of attraction attracts the tourists involved, including countries and private actors who see the opportunity, especially countries with Muslim population where they continue to develop halal tourism products so that tourists are interested in visiting facilities and infrastructure in accordance with Shariah provisions. In addition, the tourism industry is also involved in the development of halal tourism, for example, providing sharia-based tour and travel packages, restaurants, hotels, and spas with halal certification issued by the Indonesian Council of Scholars (MUI).
Indonesia has the largest Muslim population in the world, so it is very conducive to welcoming Muslim travelers. With the growth of the sharia industry and trade in Indonesia, the guarantee of elasticity and sharia compliance is increasing. In addition, there were also well established and professional Sharia / halal tourism industry actors. Increasing the number of Muslim tourists from year to year is an opportunity.

Indonesia has 8 World Heritage Cultural Sites that can host International Exhibitions and Festivals. Ranked 39th in the Cultural Heritage of 139 countries by the WEF and has the power competing in natural resources ranked 17 out of 139 countries. The incredible diversity of biodiversity has made Indonesia an extremely important part of Asia.

Head of the Tourism Ministry's accelerated halal tourism development explained how the halal tourism sector was highly developed because of its potential market. The Assistant of Tourism Development Deputy Minister explained how halal tourism will be an important pillar of national tourism and will continue to be developed to be the best and targeted to be the world's number one in 2019 .

In 2011 the expenditure of Muslim tourists in various tourist destinations around the country is estimated to reach USD 126 billion and this number is expected to rise to USD 192 billion by 2020 . In 2017, the total number of travels of global Muslim international travelers reaching 131 million people. By 2020, the number is projected to increase to 156 million and turnover is expected to reach USD220 billion [11]. This will be an excellent opportunity for halal tourism development in Indonesia. The main thing in the development of halal tourism is the marketing target to be mastered, one of which is to see the countries with the largest Muslim population in the world. Indonesia in this regard is a great opportunity in the development of halal tourism.

The Muslim population currently accounts for about 30 percent of the world's total population. The Muslim population is expected to increase over the years. The increase is higher than other religious populations [12]. It is estimated that the Muslim population between 2015 and 2060 will increase by 70 percent, while the world's population will increase by 32 percent or the total world population by 2060 by 9.6 billion people. It also signifies that Muslim tourists will continue to grow. By 2020, Muslim travelers are expected to increase by 30 percent and increase their spending value to 200 billion USD [13].

The subsequent acts of terrorism that have plagued Indonesia have had a huge impact on this nation. Some countries issue travel bans and travel advisory to their citizens to temporarily stop visiting Indonesia. This has had a significant impact on the tourism sector and has also affected Indonesia's image in the eyes of the world. The terrorist bombardment of Indonesia's image as a safe tourism destination later led the Indonesian government to diplomats the international community through a tourism campaign.

Another challenge in the development of halal tourism is that there is no comprehensive regulation of halal tourism in Indonesia. The legal basis for lawful tourism activities is based on Article Number 10 of the year 2009 about Tourism on Independence. Whereas there was a Ministerial Regulation Tourism and Creative Economy Number 2 of 2014 on the Syariah Hotel Business Administration 
Guidelines, but the Regulation was revoked by the Minister of Tourism Regulation Number 11 of 2016 [14].

In 2016, the Indonesian Shariah Council of the Indonesian Ulama Council of DSN-MUI issued Fatwa No. 108 / DSNMUI / X / 2016 on Shariah-based Tourism Maintenance Guidelines [15]. The tourism aspects organized include hotel, spa, sauna, and massage, tourist attractions, and travel agencies. However, the fatwa would not have been effective unless it was incorporated into the ministerial form of tourism. Therefore, the government is expected to immediately establish regulatory standards regarding hotels, spas, sauna and messages, tourist attractions and travel agencies based on the DSN-MUI fatwa not yet available as a good infrastructure for halal tourism in Indonesia. For example, at this time there are not many hotels that operate according to Shariah principles and even halal certified restaurants. It is different when compared to Malaysia and Singapore which have a large number of shariah-certified hotels and restaurants from Indonesia. At least two of the above facilities are of course a unique challenge for the development of halal tourism in Indonesia. Therefore, both central and regional governments should work together to provide good Shariah-compliant facilities and facilities so that the interest of the international Muslim artist to come to Indonesia is growing.

There is no fixed governmental law on halal tourism so the next challenge may be the lack of funding. It takes 20 billion USD or about $\$ 270$ trillion and half of it is used for public use. While the Government is only able to set aside 30 trillion. Developing halal tourism one of the other challenges is marketing, because halal tourism marketing is not an easy thing. This is due to the difference between the claims of non-Muslim tourists and Muslim tourists. NonMuslim travelers may decide not to travel to tourist attractions without the presence of certain attributes. So, one of the challenges of halal tourism is how to serve nonMuslim tourists and meet their needs without clashing with the concept of halal tourism. For example, some hotels say they are a sharia hotel in their promotion, and this may not be attractive to non-Muslim travelers. Therefore, halal tourism can be a hindrance in the tourism industry sector. But it can also be a business opportunity to harness creativity and flexibility in serving the needs of Muslim and nonMuslim travelers. It can also be a study or research to solve the problem.

The Indonesian government is trying to rebuild Indonesia's tourism image which has been slowing down through various public diplomacy activities through the Visit Indonesia Year 2008 campaign and Wonderful Indonesia. In August 2016, Indonesia's Halal Tourism which previously used the term sharia tourism was officially announced by the Ministry of Tourism. Indonesia's Halal Tourism with Indonesia's Halal Tourism tagline, The Halal Wonders, is a series of active efforts and government commitments to enhance Indonesia's image in all segments of the Muslim world. The concept of Indonesia's halal tourism which is currently being developed is expected to be affordable to be a media in building good perceptions about Indonesia and strengthening Indonesia's position in the international eye.

\section{E. The Efforts of Indonesia in Developing Halal Tourism}

For the development of halal tourism not missed from the supported of community and government in developing the tourism, where the role of community and government really help in the development of a new product from tourism. With Indonesia become the largest country of Muslim in the world make government of Indonesia itself in helping the community in developing this halal tourism. One of it was with doing the welfare and a program that involving the halal tourism.

The halal Tourism can't be missed from the support of the welfare of the central government and local government in the form of consent and legal protection or the legal foundation in governance protection of halal wisata. When there no legal basis, then the developing of halal tourism will be inhibited it will even be stopped in the development in a mean time. This matter really important so that the governance of halal tourism have a proper guideline.

Indonesia in making a legal law that strengthen the developing of halal tourism that based on Pancasila and UUD 1945, which is:

First, Article (UU) No. 10 in the year 2009 about the Tourism.

The first point UU No. 10 in 2009 where it explained that tourism held with the upholding principle a religious norm and value of culture as the embodiment from the concept in balancing of relationship between human and The Almighty God, the relationship between all the human, and the relationship between human and environment. This become the basis in developing of halal tourism where the value of Islam become the main point in development of halal tourism.

Second, Article (UU) No. 33 in 2014 about the Warranty of Halal Product.

Halal product really focused on in the consumption of drinks and food where we know the halal mean the drinks and food is being tested the goodness for whom consume it. Drinks and foods are the main point that need to observe in doing the travel, where the major human needs that is food, this matter will make the tourist really focused on the halal product that have in Indonesia. Not only drinks and foods, this is the warranty for all the product in the circle of halal tourism.

The Government is very focus on the halal of the product that have in the environment of halal tourism in Indonesia with doing a one rule exists talk about the halal food which is by doing the UU about halal product with the cooperation with the Board of Indonesian Ulama (MUI). Halal mean which is written in Al-Qur'an A and As-sunnah, which is resulted between halal and non-halal are not just anyone can make the decision of the resulted. Because of that, the expert appointed person need to make sure of it and the tested in following the true Islamic law which based on Al-Qur'an and As-sunnah.

Other virtues that government been doing which is by creating an acceleration team of developing the halal tourism that which are issued by the result of The Ministry of Tourism at KM.36/OT.001/MP/2016 about the Acceleration Team in Developing Halal Tourism. In this matter, the Ministry of Tourism formed of special team of halal tourism to make a significant in increasing competitiveness in halal 
tourism and start a campaign program of halal tourism in 2016-2019.

Other references that Indonesia do in developing the halal tourism is government make a rule which is PP No. 50 year 2011 about the Master Plan Development of Indonesian Tourism, PP No. 52 year 2012 about the Competency Certification and Effort Certification at the field of tourism, and PP No. 31 at 2019 about the Warranty of Halal Product.

In the president regulation have a regulation No. 63 year 2014 about the Supervision of Tourism in controlling and administer [16], the regulation No. 64 year 2014 about the Coordination Strategy Sector Trajectory Maintenance of Tourism [17] and regulations No. 2 year 2015 about the National Middle Range Development Plan (RPJMN) [18].

Other rules are the minister decisions, is Decree of Health Republik of Indonesia No. 1098/MENKES/SK/VII/2003 about the Requirements of Hygiene Sanitation and Restaurants, and Decree tourism No. 55 year 2016 about the Overflow Authority Scope Extension Effort Certification Field of Tourism [19]. In ministerial regulations is the Minister of Tourism regulations Republik of Indonesia No. 12 year 2016 about the Changes on Tourism of Ministerial Regulations. Minister's regulation Republik Indonesia No. 18 year 2016 about Business Registration Tourism, Minister's regulation Republik of Indonesia No. 14 year 2016 about the Destination Guidelines of Province Development and City District, and Minister's regulation No. 11 year 2015 about the Tourism Field of the Enactment Standart of National Work Competency.

The local government related to the halal tourism have regulations and decisions, which is local regulation which govern on the local destinations of halal tourism and the Governor rules, regent/mayor about halal tourism. One of the example are the supported of local government in development of halal tourism which is local Province Nusa Tenggara Barat (NTB) become the one and only province that have local rule about halal tourism which contained in local regulation number 2 year 2016 about halal/sharia tourism.

\section{F. Collaborating with various Boards}

Ministry of Tourism in collaboration with the National Shariah Council (DSN), the Indonesian Scholars Council (MUI) and the Business Certification Board (LSU). The concrete form of the cooperation is to develop tourism as well as to promote the culture and values of religion which will then be poured into the Regulations of the Minister of Tourism and the Creative Economy.

The government is also working with the Indonesian Hotel and Restaurant Association (PHRI) to provide halal lodging and dining that serves halal food menus and is also working with the Association of the Indonesia Tours and Travel (ASITA) to create halal tourist packages religion [20].

\section{G. Creating Achievement Mission in Halal Travel}

The Indonesian government, in particular the Ministry of Tourism, currently has six main targets for the period 20142019.

First, tourism's contribution to Gross Domestic Product (GDP) increased from 9\% in 2014 to 15 percent in 2019.
Until November 2015, tourism's contribution to GDP was $9.5 \%$.

Second, foreign exchange increased from Rp 140 trillion in 2014 to $\mathrm{Rp} 280$ trillion in 2019. Currently tourism contribution to National GDP is estimated to reach 4 percent with foreign exchange of Rp 155 trillion.

Third, contributions to employment opportunities increased from 11 million in 2014 to 13 million in 2019.

Fourth, the tourism competitiveness index increased from 70 in 2014 to 30 in 2019.

Fifth, the number of foreign tourists (wisman) arrivals increased from 9.4 million in 2014 to 20 million in 2019. As of September 2015, the number of tourists was 8.69 million. Sixth, the number of national tourist trips increased from 250 million in 2014 to 275 million in 2019 [21].

To achieve these six targets, Indonesia grouped Indonesian tourism products into 3 major products offered, namely culture, nature, and man-made products with the following composition:

First, Nature tours include sea tours, adventure tours, and ecotourism.

Second, Cultural tours that include cultural and historical heritage, shopping and culinary tours, city, and village tours.

Third, Artificial Travel that includes MICE tours, sports tours, and integrated tours.

\section{H. Introduction to Halal Tourism}

In addition to preparing Halal Tourism destinations, Muslim-friendly hotels and halal tourism bureaus, the Ministry of Tourism has also undertaken various activities to introduce halal tourism to the international Muslim community, following the activities of the Indonesian Halal Tourism campaign:

First, the launch of the Indonesia Halal Tourism or Halal Tourism Indonesia brand as a country branding that reflects the natural beauty, diversity of cultural arts, and traditions, and the harmony of Indonesian people's life.

Second, The Ministry of Tourism is implementing the POSE (paid media, owned media, social media, and endorser) strategy in implementing Indonesia Halal Tourism campaign. Paid Media: Islamic Finder, MNC Muslim, HalalBooking.com, British Muslim, The Muslim Travel Girl, Zhabihah Channel, YouTube, TripAdvisor, and Google. An Owned Media: Ministry of Tourism launches the official website of Indonesia Halal Tourism with the domain name http://halaltourism.id/ Social Media: Instagram (@kemenpar dan @indtravel), Facebook (Ministry of Tourism), Twitter (kemenpar_RI), and Indonesia's Garuda Cooperation Blog run by Ministry of Tourism staff. Endorser: The Ministry of Tourism has appointed a number of national celebrities to become Halal Tourism Ambassadors, such as Asma Nadia (Novel Researcher), Laudya Cytia Bella (Actress), and Dian Rainbow (Fashion Designer).

Third, Halal Tourism Campaign or Halal Tourism Indonesia by the Ministry of Tourism through Festivals and Expo. Ministry of Tourism promotes and introduces Indonesian Halal Tourism to the Middle East community through Arabian Travel Market (ATM) 2016 in Dubai, promotions and exhibitions of Indonesian Halal Tourism by hosting the Riyadh Travel Show (RTS) on April 12-15, 
2016, Tourism Ministry following Malaysia International Halal Showcase (MINHAS) 2016 and 2017 in Kuala Lumpur.

Forth, Embassy of the Republic of Indonesia (KBRI) Norway promotes Western Sumatra as World's Best Halal Destination 2016 and World's Best Halal Culinary Destination 2016 at the Reiselivsmessen Exhibition which is the annual Nordic Exercise Exhibition on January 13-15, 2017, the Embassy of the Republic Pakistan (KBRI) Pakistan participated in the conference and international exhibition of the halal industry sector organized by the Punjab Halal Development Agency (PHDA) in April 2017 in Islamabad.

Fifth, Familiarization Trip programme (Fam Trip), Fam Trip is a series of programs designed to introduce and provide insight into Indonesia's tourism, culinary and cultural potential for agents travel, mass media, and author of bloggers (bloggers). From March 29 to April 2, 2016, the Ministry of Tourism and Embassy Kuala Lumpur invited ten travel agents and tour operators and ten Malaysian journalists to Lombok to introduce halal tourism destinations for Pulai Thousand Mosques, Ministry of Tourism with KBRI Jeddah called Fam Trip by inviting six journalists and a social media celebrity from Saudi Arabia. The program theme of King Salman Route which is to elucidate the course of Salman during a visit to Indonesia, the Indonesian Embassy in the United Arab Emirates held a Fam Trip to invite journalists of the national television station of the Middle East on May 21, 2017, to look directly Lombok, West Sumatra, Aceh, West Java, and Jakarta [22].

As the view of visitors from Muslim countries specially from middle east countries see figure below.

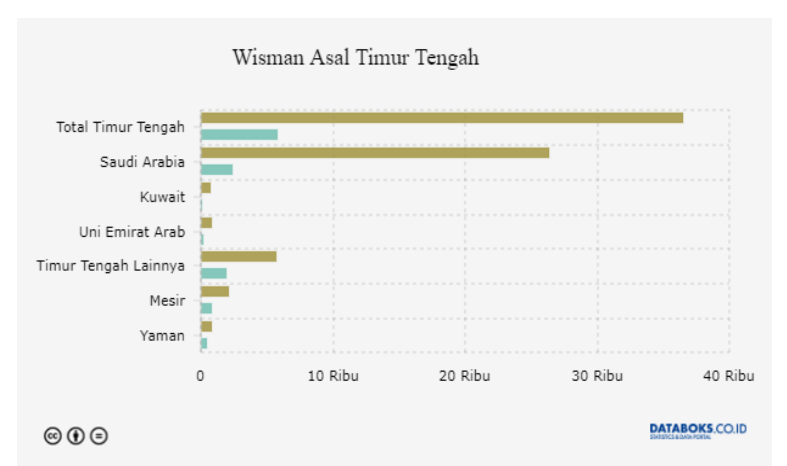

Fig. II. Tourists from middle east 2019 [23].

The Ministry of Tourism has also regularly conducted technical guidance (bimtek) as well as workshops on 10 top halal tourism destinations. Indonesia is also launching a new program that will drive this halal tourism industry by launching a program called Indonesia Muslim Travel Index (IMTI). This program refers to the values of GMTI, only more specifically to develop Indonesia's halal tourism to grow and to showcase Indonesia's friendly destination destinations to Muslim travelers with various criteria [24].

\section{Impact of Traveler Visits after Indonesia Becomes the World's Best Halal Traveler}

Indonesia is experiencing an increasing number of foreign tourists. The Central Bureau of Statistics (BPS) has recorded a Middle Eastern country (wisman) traveling to Indonesia in rapid succession. By June 2019, Middle Eastern travel sales of 36.5 thousand were up $529 \%$ or fivefold compared to the previous month for only 5.8 thousand. The largest growth was in the foreign tourists of Saudi Arabia, up 1.002.55\% from 2.4 thousand to 26.4 thousand visits [25].

The next major growth came from the foreign tourists who came from the United Arab Emirates and Kuwait. Foreign tourists from the United Arab Emirates rose $315.96 \%$ from 200 visits to 800 visits, while from Kuwait increased $536.45 \%$ from 100 visits to 700 visits. From Indonesia's halal tourism market Growth in 2018 reached $18 \%$, with the number of foreign Muslim tourists visiting Indonesia's priority halal tourist destinations reaching 2.8 million with foreign exchange reaching more than $\mathrm{Rp} 40$ trillion. Based on the target of reaching 20 million foreign tourists (wisman) visits by 2019, the Ministry of Tourism targets $25 \%$ or 5 million of the 20 million tourists who are Muslim tourists [26].

One example of a halal tourist destination that most Muslim tourists love is Lombok. Lombok is an area heavily favoured by foreign tourists, especially Muslims. With the title held by the mines as the best halal tourist destination in the world and the best halal honeymoon destination in the world, it has become Indonesia's unique destination in the eyes of the world.

The Proof of the success of this halal tourism development has led to an increase in the number of foreign tourists. But success is not something we should be proud of, which is a very difficult way to maintain a halal tourism presence in the world. Indonesia has its own challenges, where people still do not understand the details of halal tourism.

\section{CONCLUSION}

The policy is in the form of legal law become the foundation and mold in the development of halal tourism at Indonesia. Some policies have made by using the support of the development of halal tourism. But this is a must have side by side with the community understanding of the halal tourism itself until there is no misunderstanding by the end of poor judgement in the policies. The cooperation become one of the things that can speed up the development of halal tourism in Indonesia. One of them is the cooperation with the relevant agencies with the development of halal tourism and create some goals that achieve some goals.

Other steps that Indonesia taken in the development of halal tourism is with introduced the halal tourism of Indonesia to the International Muslim community with the variety of campaigns that have been doing by the coordination from the ministry of tourism, one of it was through the social media internet, by doing some exhibition and festival that was carried out at Indonesia or any other country and do some promotion or big discount that can attracted the International travelers.

Indonesia has finally got the first stage in become the halal tourism the best number one in the world in version of Global Muslim Travel Index (GMTI) in April 2019 and recently Indonesia got another award which is the tourism with the best destination of the world in version CNTraveller.com. 
This has become the positive impact in the development of halal tourism Indonesia. With the variety of performance that have become the outline improvement in the total of the travel that must happen. The visit of foreign tourism at the year 2019 have total up to 12,27 million. The total has improved by $2,63 \%$ compare with the total of the Muslim visitor tourism at year 2018 have total up to 11,96 million.

\section{REFERENCES}

[1] https://www.inews.id., 2018. Accessed February 12020.

[2] Moleong, J., Lexy. Metode Penelitian Kualitatif. Bandung: Rosda, pp. $17,2017$.

[3] [3]Https://www.bps.go.id/pressrelease/2019/11/01/1617/jumlahkunjungan-wisman-ke-indonesia-september-2019-mencapai-1-40juta-kunjungan-.html. Accessed February 52020.

[4] Https://www.kbbi.web.id. Accessed February 12020.

[5] Undang-Undang Republik Indonesia Nomor 10 Tahun 2009 tentang Kepariwisataan

[6] Subarkah, Ridho, Alwafi. Potensi dan Prospek WisataHalal Dalam Meningkatkan Ekonomi Daerah (Studi Kasus: Nusa Tenggara Barat), Jurnal Sospol, Vol. 4 no. 2 (Juli-Desember, 2018) pp. $42-79$ melalui http://ejournal.umm.

ac.id/index.php/sospol/article/viewFile/5979/6094 accessed on August 172019.

[7] Tim Penyusun. Pedoman Pariwisata Halal Jawa Barat, Konsorsium Halal Jawa Barat, pp. 5-15, 2019.

[8] https://www.mui.or.id. Accessed February 52020.

[9] https://sofyancorp.com. Hospitality and Tourism. Accessed February 5 2020.

[10] https://www.kemenpar.go.id/post/narasi-tunggal-5-tahunkembangkan-pariwisata-halal-indonesia-akhirnya-raih-peringkatpertama-wisata-halal-dunia-2019.

[11] https://ahl.com. Accessed February 12020.

[12] htpps://www.pewresearch.org. Accessed 5 February 52020.

[13] htpps://www.pewresearch.org. Accessed 5 February 52020.

[14] Peraturan Pemerintah No. 50 Tahun 2011 Tentang Rencana Induk Pembangunan Kepariwisataan Indonesia, PP No. 52 Tahun 2012 Tentang Sertifikasi Kompetensi dan Sertifikasi Usaha di Bidang Pariwisata, dan PP No. 31 Tahun 2019 Tentang Jaminan Produk Halal, pp. 7-11, 2019.

[15] Peraturan Presiden No. 63 Tahun 2014 Tentang Pengawasan dan Pengendalian Penyelenggaraan Kepariwisataan, pp. 1-15, 2014.

[16] Peraturan Presiden No. 64 Tahun 2014 Tentang Koordinasi Strategis Lintas Sektor Penyelenggaraan Kepariwisataan, pp. 1-20, 2014.

[17] Peraturan Presiden No. 2 Tahun 2015 Tentang RPJMN, pp. 1-25, 2015.

[18] Elsa Assari. Pengembangan wisata pulau merah sebagai wisata halal tinjauan fatwa DSN-MUI Nomor: 108/DSN-MUI/X/2016 tentang pedoman penyelenggaraan pariwisata berdasarkan prinsip syariah (skripsi). Malang (ID): Universitas Islam Negri Maulana Malik Ibrahim, pp. 20-35, 2017.

[19] Keputusan Menteri Kesehatan RI No. 1098/MENKES/ SK/VII/2003 tentang Persyaratan Hygiene Sanitasi Rumah Makan dan Restoran, dan Kepmen Pariwisata No. 55 Tahun 2016, pp. 1-13, 2016.

[20] Satriana, Dewi, Eka. Wisata Halal: Perkembangan, Peluang, dan Tantangan. Surabaya, Pusat Riset dan Pengembangan Produk Halal Universitas Airlangga, pp. 15-35, 2018.

[21] http://www.kemenpar.go.id/. Accessed February 12020.

[22] Satriana, Dewi, Eka dan Faridah, Durrotul, Hayyun. Wisata Halal: Perkembangan, Peluang, dan Tantangan. Journal of Halal Product and Research (JHPR) Vol. 01 No.02, Mei-November 2018, Universitas Airlangga, pp. 15-40, 2018.

[23] https://databoks.katadata.co.id/datapublish/2019/08/02/kunjunganwisman-timur-tengah-naik-lima-kali-lipat.

[24] https://kominfo.go.id. Accessed February 12020.

[25] https://www.bps.go.id. Accessed February 12020.

[26] https://www.setkab.co.id. Accessed February 12020.

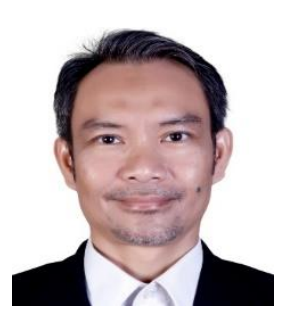

Anton Minardi is Associate Professor at International Relations Department Pasundan University Bandung Indonesia. His activities including research, write, speak, and involve in social development. He wrote some books including politics, international relations, and Islamic reviews.

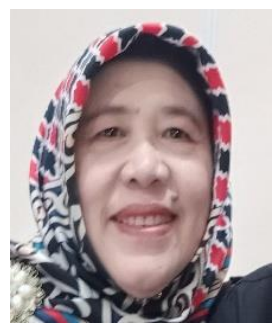

Dewi Astuti is Associate Professor at International Relations Department Pasundan University Bandung Indonesia. Now she active in research office in the University.

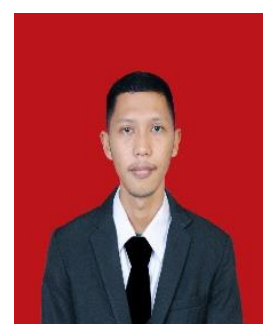

Suhadi is Research Assistant at International Relations Department Pasundan University Bandung Indonesia. He is a writer and social volunteer. 